\title{
ANALYSIS OF BEHAVIOUR OF CALCIUM SILICATE HOLLOW BLOCKS MASONRY SUBJECTED TO THE CONCENTRATED LOAD
}

\author{
Mindaugas ZAVALIS \\ Vilnius Gediminas Technical University, Vilnius, Lithuania \\ Received 01 July 2020; accepted 20 November 2020
}

\begin{abstract}
Loading of masonry with concentrated load is a sufficiently common case of loading which occurs due to structures of various purposes and sizes which lean against masonry wall, column or partition wall. Reinforced concrete or metal beams, reinforced beams, wooden structures of roof or span are leaned against masonry structures most usually. Investigations show that masonry structures under concentrated load withstand higher loads than structures of which the whole surface area is compressed. In most cases traditional bricks' masonry under concentrated load was investigated. Its head joints are filled with mortar.

This paper describes the experimental and numerical modeling results of investigation of calcium silicate hollow blocks masonry with thin layered mortar and unfilled head joints compressed by concentrated load. The more dangerous case when the edge of masonry unit (wall) is affected by concentrated load was chosen for analysis. Preliminary investigations have shown that the bed joints transmiss horizontal stresses. The stress distribution angle is close to $60^{\circ}$, i.e. close to stress distribution in masonry with filled head joints.
\end{abstract}

Keywords: calcium silicate hollow blocks, concentrated load, compressive strength, numerical modeling.

\section{Introduction}

In order to analyse masonry according to the area of surface under load two cases of compressive load may be distinguished. The first one, when whole masonry surface area is affected by uniform compressive load, and the second one, when masonry is affected by concentrated compressive load. The size of loaded compressed surface area of masonry structure is one of characteristics by which masonry load cases may be distinguished. Concentrated load affects only part of masonry wall surface area, and the rest part of the wall stays unloaded. Concentrated load may occur in different places of wall surface: at the center or at the edge. Area of loaded surface (contact area) is different as well, this area can encompass whole height of masonry structure cross section or it may be limited to the part of it, depending on the leaned structure type and size, as well on the nature of leaned structure (support width, depth, etc.).

Loading of masonry with concentrated load is a sufficiently common case of loading which occurs due to structures of various purposes and sizes which lean against masonry wall, column or partition wall. Reinforced concrete or metal beams, reinforced beams, wooden structu- res of roof or span are leaned against masonry structures most usually.

Masonry structures under concentrated load withstand higher loads than structures of which the whole surface area is compressed. This increase in structural strength after experiments was first identified and described by German scientist Johan Bauschinger (Onischick, 1939). The increase in compressive strength is estimated by a coefficient which depends on the ratio of structure surface effective area A to the load area under concentrated load $A_{b}$. The dependence derived by the aforementioned scientist describing the increase of compressive strength $f_{d}$ (under compressive concentrated load), published in 1876, is still recommended in some design norms:

$$
f_{u d}=f_{d} \sqrt[3]{\frac{A}{A_{b}}} .
$$

However, this is not the only calculation method proposed. In 1923 scientist Morsh after experimental tests proposed a square root formula to estimate local compression which is used in German calculation norms and Eu-

${ }^{*}$ Corresponding author. E-mail: mindaugas.zavalis@vilniustech.lt 
rocode 2 (Europen Commitee for Standartization [CEN], 2005; Venckevičius, 2005).

Both experiments and calculations show that compressive strength of masonry under concentrated load is higher than compressive strength of masonry under evenly distributed load (Symakezis \& Asteris, 1999).

Making an assumption that masonry structure is continual elastic body, it is possible to estimate the increase of strength of compressed structure by applying methodology of classical elasticity theory according to theory of force affected by half-plane (Atkočiūnas \& Nagevičius, 2004).

Huge local stresses occur in masonry due to concentrated load. Triaxial compressive stresses occur in an area subjected to load, and in the area slightly below, the pattern of stress action changes: compressive stresses act towards direction of applied force and tensile stresses act perpendicular to it (Page \& Hendry, 1988).

Analyzing the factors that determine the increase of the compressive strength of masonry, it is first observed that the increase in strength is due to the effect of the unloaded surface area of the masonry structure. Unloaded or less loaded part of masonry "helps" to the part of masonry under concentrated load. Less loaded part of masonry restricts transversal strains of more loaded part of masonry, therefore the clamping effect occurs on the part of the masonry subjected to the concentrated load (Onischick, 1939).

A number of studies have been carried out on concrete elements under concentrated load (Page \& Hendry, 1988). However, the authors argue (Page \& Hendry, 1988) that properties of concrete structures cannot be directly attributed to the properties of masonry structures, and concrete structures are more continual units than masonry structures. Behaviour of masonry is affected by mortar joints, the stiffness of which differs in masonry units and the joints are as weakening sections affected by tensile stresses (Page \& Hendry, 1988).

Compressive strength of compressed masonry depends on restrictions of transversal strains in compressed masonry. If the ratio of the loaded area to the effective area is small, the strength of masonry increases significantly. The difference with evenly loaded masonry load-bearing can be up to three times (Vermeltfoort, 2005).

However, the ratio of loaded area is not the only factor which determines increase of masonry strength. Many other factors determine increase of masonry compressive strength, such as ratio of loaded area and cross section of wall surface area (loaded area ratio), the place of adding the force in relation to the surface area of the wall, geometry of loaded wall and load adding method (Page \& Hendry, 1988). It was estimated according to the research of other authors that connection joints between masonry units and mortar joints as well as masonry laying method (i.e. distribution of masonry units (Angelillo et al., 2014) as well as form of masonry units, size and distribution of hollows (Zavalis et al., 2018) impact loaded masonry behaviour.
Sufficient experimental studies of masonry under concentrated compressive load have been carried out, but the experimental results obtained are characterized by a very high dissemination due to the different types of masonry being tested (Page \& Hendry, 1988).

In most cases traditional bricks masonry under concentrated load was investigated, in it head joints are filled with mortar. Using high precision calcium silicate hollow blocks, head joints are not filled with mortar. Therefore, the contact of masonry units is characterized by a certain submissive behaviour. Stresses in horizontal direction in such a masonry are transmissed mostly through head joints. The results of research on such masonry loaded with concentrated load are few in the literature. In this case, the question arises as to whether the same assumptions as for traditional brick masonry with filled head joints can be applied in determining the strength of such a masonry subjected to the concentrated load.

The aim of this research - to analyze behaviour of calcium silicate hollow blocks masonry with thin layered mortar and unfilled head joints while compressing it with concentrated load. The most dangerous case was chosen for analysis, when the edge of masonry unit (wall) is subjected to the concentrated load.

\section{Experimental study and comparison with the results of numerical modeling}

In order to perform the analysis of the behaviour of compressed masonry, the article presents a comparison of the results obtained in the laboratory experiment with the calculations of the numerical finite element model. An experiment of one of the most popular types of masonry (calcium silicate hollow block masonry with unfilled head joints) (see Figure 1) was selected for the study. It was performed in Vilnius Gediminas Technical University, Laboratory of the Department of Reinforced Concrete Structures and Geotechnics (Jonaitis, 2005).

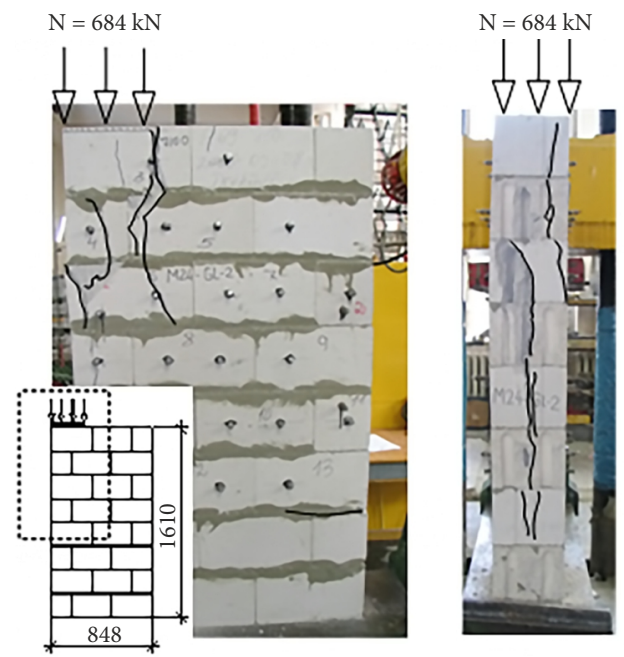

Figure 1. Failure mode of compressed masonry under bearing load $684 \mathrm{kN}$ 
After the analysis of the types of numerical modeling applied in practice (Roca et al., 1998), a decision was made to solve the problem of numerical modeling of the performed laboratory test by applying simplified type micromodeling.

\section{Description of laboratory sample}

As it is seen, masonry sample made from calcium silicate hollow blocks M24 (240×198×340, hollowness $22.62 \%)$ was prepared, the height of which was $1.61 \mathrm{~m}$, width $0.848 \mathrm{~m}$. Normalized compressive strength of blocks 20.6 MPa. $2 \mathrm{~mm}$ thickness bed joints of masonry fragment were formed from thin layered masonry mixture Mira 5010 Block Glue, which average compressive strength 7.06 MPa. (LST EN 1015-11, Lietuvos standartizacijos departamentas, 2004), and head joints left unfilled, blocks were moistened. Sample was subjected to concentrated static short term load, which was added at the edge of sample through whole thickness of sample, load section length $250 \mathrm{~mm}$. During experiment deformations were measured with strain gauges. Bearing compressive load and sample strains with increasing local load were estimated for described sample.

As it is seen from Figure 1, the sample collapsed due to vertical and horizontal cracks which opened under $684 \mathrm{kN}$. compressive load.

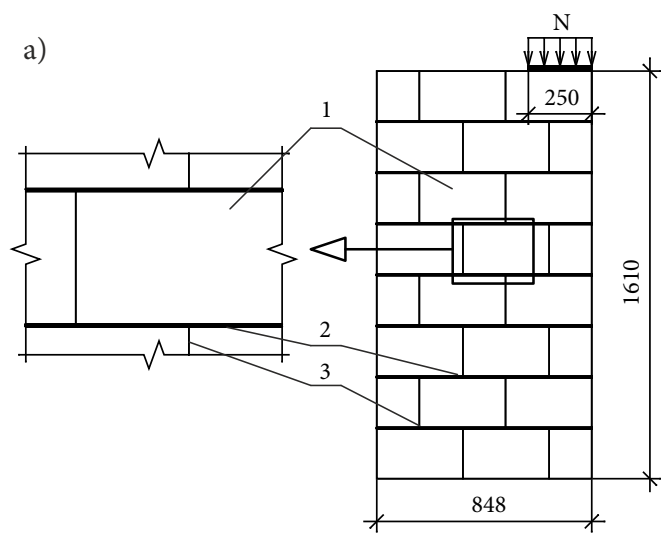

\section{Numerical modeling of masonry subjected to concentrated load}

To solve the problem of numerical modeling the numerical model based on the sample scheme presented in Figure 2 was prepared. To perform analytical analysis of state of stress the numerical model of compressed calcium silicate hollow blocks masonry fragment was made, which was realized using software "Diana". Simplified method of micromodeling was used while making numerical model of the sample.

Numerical model was made for calcium silicate hollow blocks masonry with thin layered mortar bed joints. Head joints of sample were left unfilled. Fragment test scheme is presented in Figure 2.

Applying the rules of simplified modeling, the simplified model geometry corresponding to the sample scheme was first created. The numerical model of the sample is formed by changing the bed joints into blocks of enlarged dimensions (Angelillo et al., 2014; Lourenco et al., 1995; Roca et al., 1998; Senthivel \& Lourenco, 2009). Process of changing is presented in Figure 3.

In the numerical model, the calcium silicate blocks are modeled in a simplified forms, that is, without hollows. The blocks are assumed to be isotropic. The blocks are broken down into finite tetraedrical elements with physical and mechanical properties of units. In contact areas
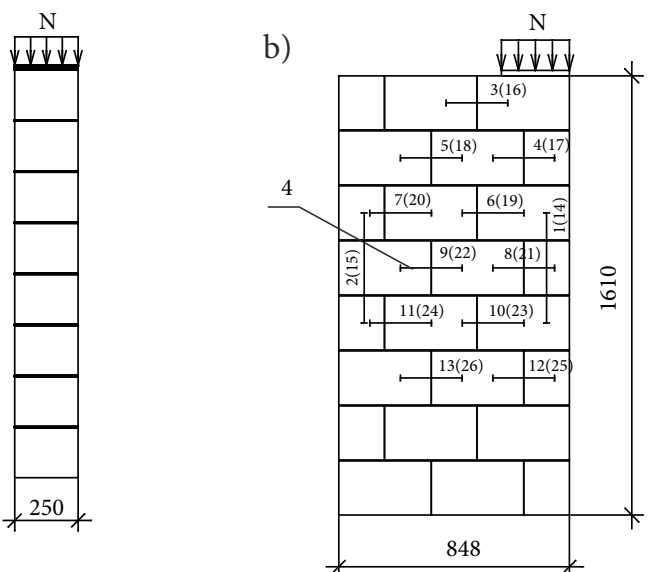

Figure 2. Test scheme of calcium silicate hollow blocks masonry wall compressed at the edge: a) fragment of wall; b) test scheme for wall fragment with measuring gauges: 1 - calcium silicate block; 2 - thin layered mortar bed joint; 3 - unfilled head joint
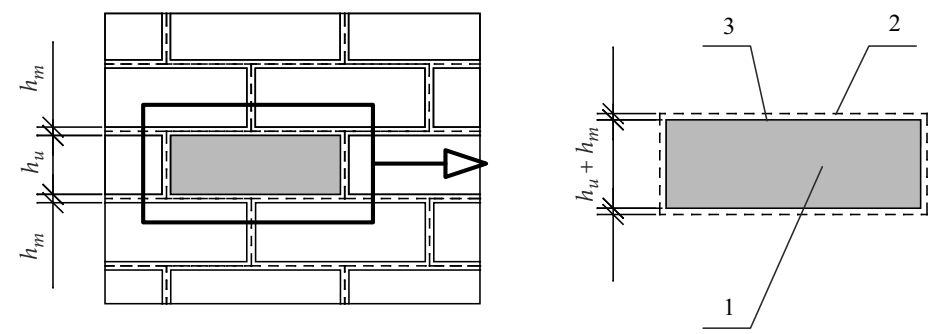

Figure 3. Scheme of simplified modeling: $h_{u}$ - unit height; $h_{m}$ - bed joint height; 1 - continual element; 2 - contact area; 3 - area of potential opening of crack (Lourenco et al., 1995) 

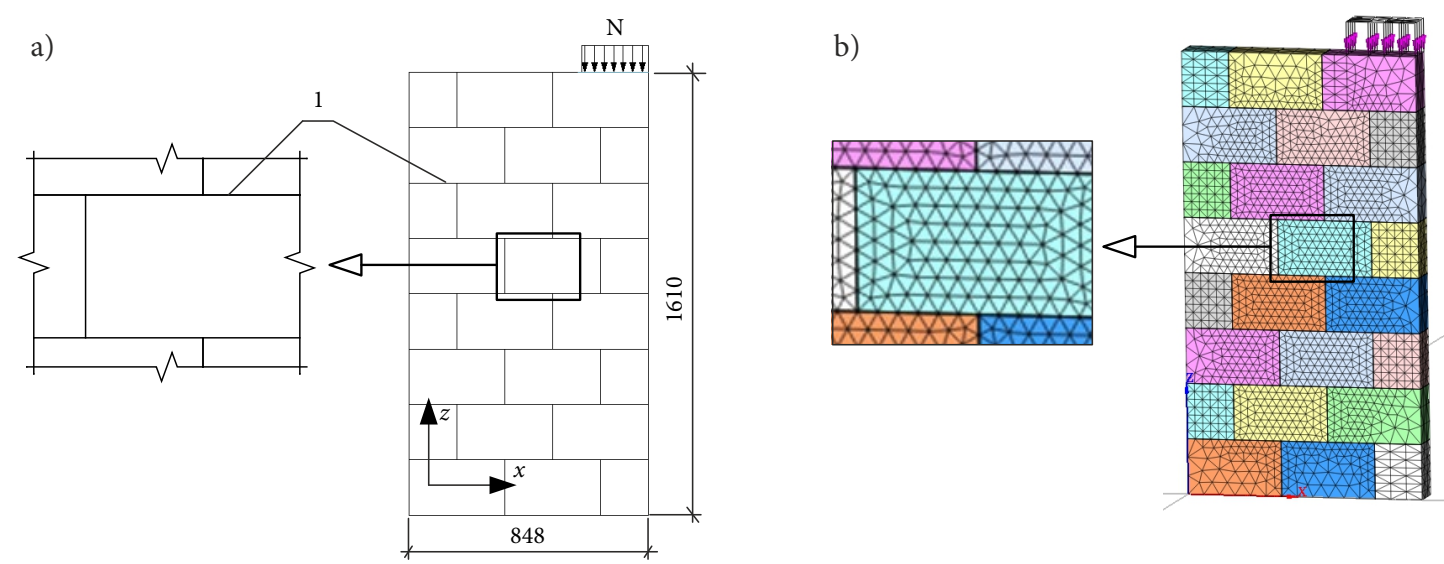

Figure 4. Numerical model of calcium silicate blocks masonry fragment: a) dimensions of fragment; b) numerical model of wall with finite elements net: 1 - blocks contact area

finite elements of blocks have common points. The numerical model developed and prepared for calculation is shown in Figure 4.

To develop numerical model (see Figure 4) the required parameters and qualities of materials are included. Parameters of materials are described based on performed studies of materials and recommendations presented in research articles. Three parameters of various materials were included in numerical model applied to blocks, bed joints, and head joints.

\section{Parameters of blocks material}

Behaviour of aforementioned elements was described using smeared crack model based on concept of fixed crack (Manie, 20011).

Behaviour of block subjected to direct tension is described according to Figure 5a, that is, according to exponential function based on estimations of block tensile strength and tensile failure energy. Tensile strength was estimated by bending prism cut from the block and obtained bending strength was recalculated according to (Angelillo et al., 2014; fib. CEB-FIP, 1998; Lourenco et al., 1995; Roca et al., 1998; Senthivel \& Lourenco, 2009) (2) formula. Failure energy of block subjected to tension is described based on methodology proposed by Lorenc:

$$
G_{f}=0025\left(2 f_{t}\right)^{07}
$$

where $f_{t}$ - tensile strength of block. a)

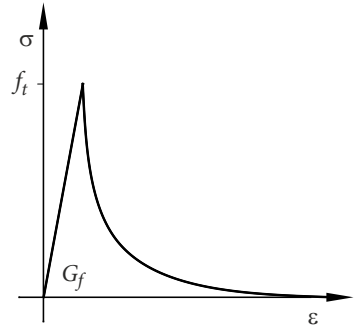

b)

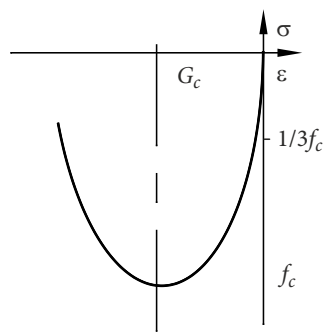

Figure 5. Graphs of masonry units' material parameters in numerical model: a) exponential function; b) parabolic function (according to TNO Diana, 2011)
Material of compressed block is described according to Figure $5 b$, that is, according to parabolic function, after estimation of block compressive strength and calculated failure energy, according to formula:

$$
G_{c}=15+043 f_{c}-00036 f_{c}^{2},
$$

where $f_{c^{*}}$ - compressive strength of calcium silicate block.

\section{Contact areas of model}

Two contact area are destined in model near unfilled head joint and bed joint with mortar. Both contact areas are modeled as areas of potential crack opening.

Unfilled head joint between blocks is modeled to take over only compressive stresses, but not tensile stresses.

Bed joint with mortar is modeled as contact area, for which failure function is included as fragile and its failure mode is shown in Figure 6 (Manie, 2011).

Tensile strength $f_{t}$ from block is estimated according to laboratory tests (Wijffels \& Adan, 2004) and is equal to $0.5 \mathrm{MPa}$. The other parameters of mortar joint, that is, normal and shear stiffness, are calculated based on methodology proposed by Lourenco (Angelillo et al., 2014; Mohammed, 2010):

$$
\begin{aligned}
& k_{n}=\frac{E_{u} E_{m}}{h_{m}\left(E_{u}-E_{m}\right)}-\text { normal stiffness of joint; } \\
& k_{\tau}=\frac{k_{n}}{2(1+v)^{2}}-\text { tangential stiffness of joint, }
\end{aligned}
$$

where $E_{u}$ - block modulus of elasticity; $E_{m}$ - mortar modulus of elasticity; $v$ - mortar Poisson's ratio.

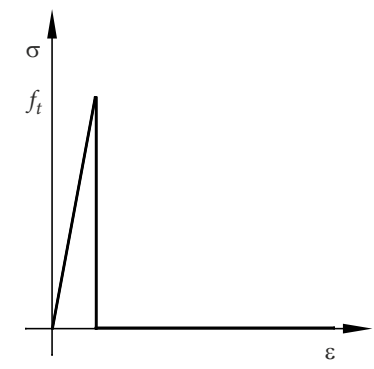

Figure 6. Failure mode of mortar joint in numerical model 
Table 1. The material parameters of the numerical model of the masonry fragment used for numerical modeling

\begin{tabular}{|l|c|l|c|l|}
\hline \multicolumn{2}{|c|}{ Parameters of blocks } & \multicolumn{2}{c|}{ Bed mortar joint } & \multirow{2}{*}{ Head mortar joint } \\
\cline { 1 - 5 } \multicolumn{1}{|c|}{ name of parameter } & Size & \multicolumn{1}{|c|}{ Name of parameter } & Size & \\
\hline Compressive strength $f_{c} \mathrm{MPa}$ & 16.46 & Tensile strength $f_{t} \mathrm{MPa}$ & 0.5 & $\begin{array}{l}\text { Unfilled head joint between } \\
\text { blocks modeled to take over only } \\
\text { compression stresses and not to take } \\
\text { over tensile stresses. }\end{array}$ \\
\hline Tensile strength $f_{t} \mathrm{MPa}$ & 2 & Modulus of elasticity $E_{m} \mathrm{MPa}$ & 8 & 4.3 \\
\hline Modulus of elasticity $E_{u} \mathrm{MPa}$ & 15 & Normal stiffness $k_{n} \mathrm{Nmm}$ & 2.97 & \\
\hline Compression failure energy $G_{c} \mathrm{Nmm} / \mathrm{mm}^{2}$ & 21.1 & Tangential stiffness $k_{\tau} \mathrm{Nmm}$ & 0.2 & \\
\hline Tension failure energy $G_{f} \mathrm{Nmm} / \mathrm{mm}^{2}$ & 0.07 & Poisson's ratio $v$ & \\
\hline
\end{tabular}

The numerical model of the sample is analyzed by applying the arch length method with Newton-Raphson iterative method. The obtained results of numerical modeling are compared with the experimental data. The analysis of the obtained results is given below.

\section{Comparison of experimental results and numerical model results}

Obtained calculations from numerical model were compared with results obtained during the experiment. First, a more detailed analysis of the stress state of the numerical model of wall was performed by creating a diagram of the most important stresses, which is shown in Figure 7. Three diagrams are presented at three different load levels: $1 \mathrm{MPa}, 10 \mathrm{MPa}$, and $15 \mathrm{MPa}$.

In Figure $7 \mathrm{a}$ a diagram of stresses in compressed masonry wall is presented when the cracks in the wall have not yet opened. At a load of 1.0 MPa, the masonry deforms elastically. As can be seen in Figure 7a, until the plastic deformation in the masonry occurs, the angle of distribution of stresses from the horizontal is equal to 60 (Bigoni \& Noselli, 2010a, 2010b).

During another stage of load, when load is equal to $10 \mathrm{MPa}$, the higher values of stresses were obtained, but impact of compressive stresses towards horizontal direction decreased (see Figure $7 \mathrm{~b}$ ) due to already opened cracks. At load of $10 \mathrm{MPa}$, plastic deformations occur in the unit. Opened horizontal cracks decrease surface area which takes over compressive stresses. Due to this reason stresses in vertical direction over the entire height of the wall are distributed in the opposite way than at load of $1 \mathrm{MPa}$. Thus, load of $10 \mathrm{MPa}$ provokes relatively uniform stresses over the entire height of the wall. And at load of $1 \mathrm{MPa}$. stresses gradually decrease.

In Figure $7 \mathrm{c}$ stresses stresses occured due to $15 \mathrm{MPa}$. load are shown. In this stage wall reaches approximately $91.4 \%$ of its bearing capacity and masonry deforms plastically. Opened cracks increase gradually. Due to this reason highest compressive stresses act in loading area. Over the entire height of wall fragment obtained stresses are uniform and are equal to approximately 16.4 MPa.

The stress distribution obtained during numerical modeling is close to tests performed by other authors (Bigoni \& Noselli, 2010a, 2010b) or numerical modeling calculations (Drobiec, 2017).

The results of experimental research and numerical modeling have shown that in both cases defined compressed masonry strains distribution character is uniform. Crack formation load estimated during experiments was equal to $684 \mathrm{kN}$, and the one estimated in numerical modeling - $545 \mathrm{kN}$. During experiment estimated bearing capacity of sample is $25.5 \%$ higher than in numerical modeling. a)

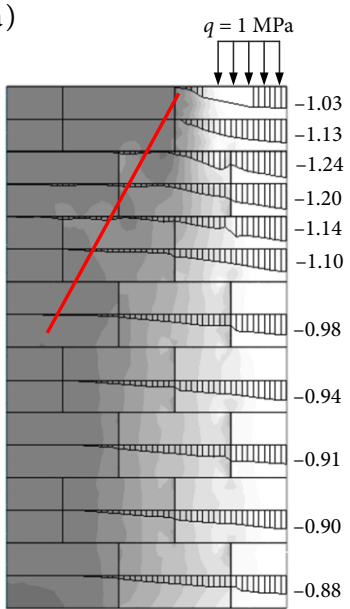

b)

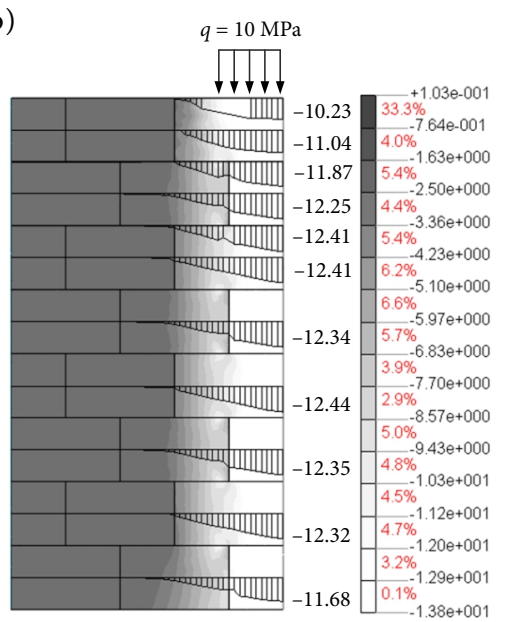

c)

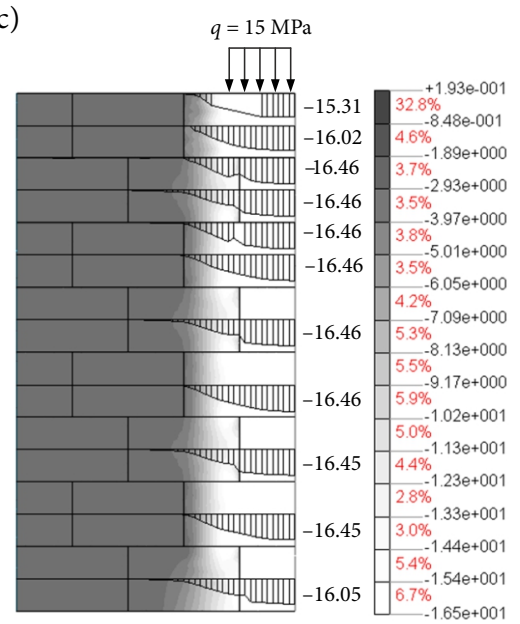

Figure 7. Distribution of main compressive stresses: a) at load of $1 \mathrm{MPa}$; b) at load of $10 \mathrm{MPa}$;) at load of $15 \mathrm{MPa}$ 
a)

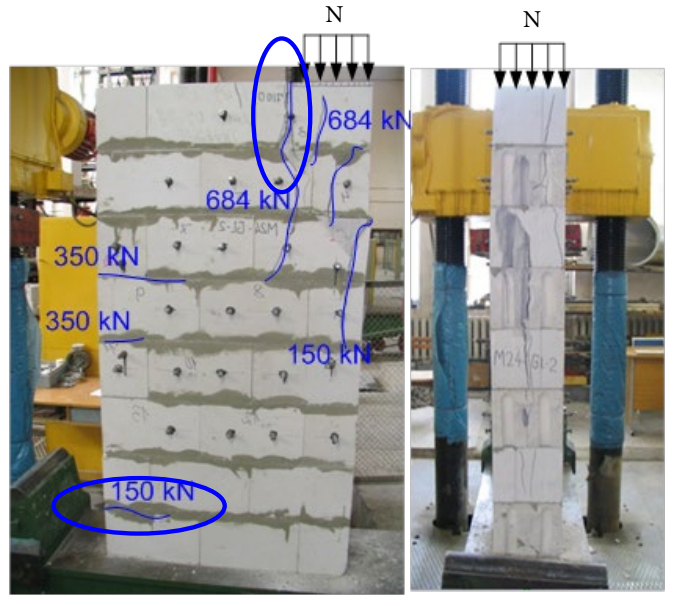

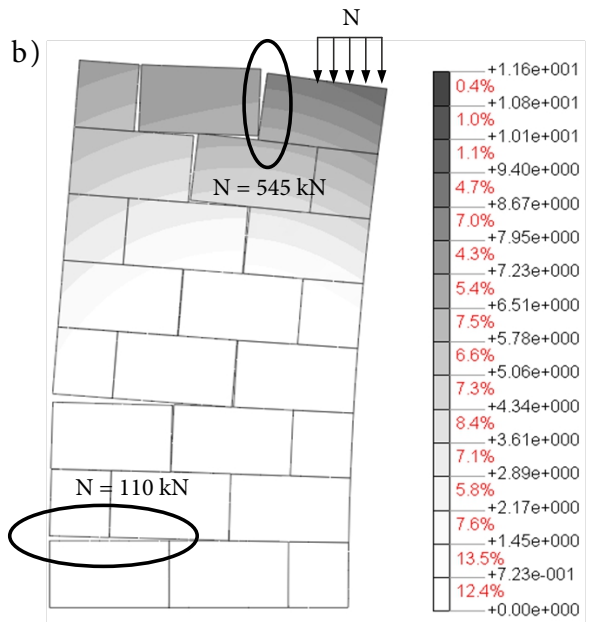

Figure 8. Cracks distribution and crack formation loads: a) experimental research; b) numerical modeling

a)

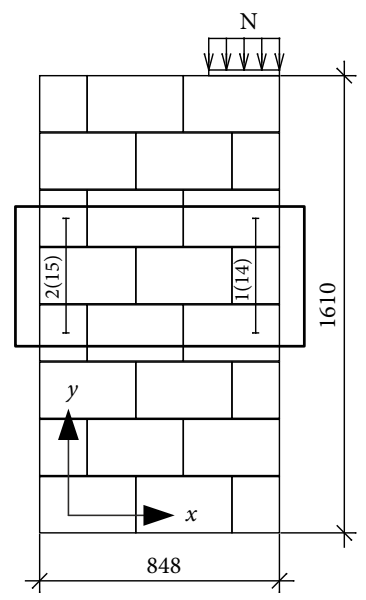

b)

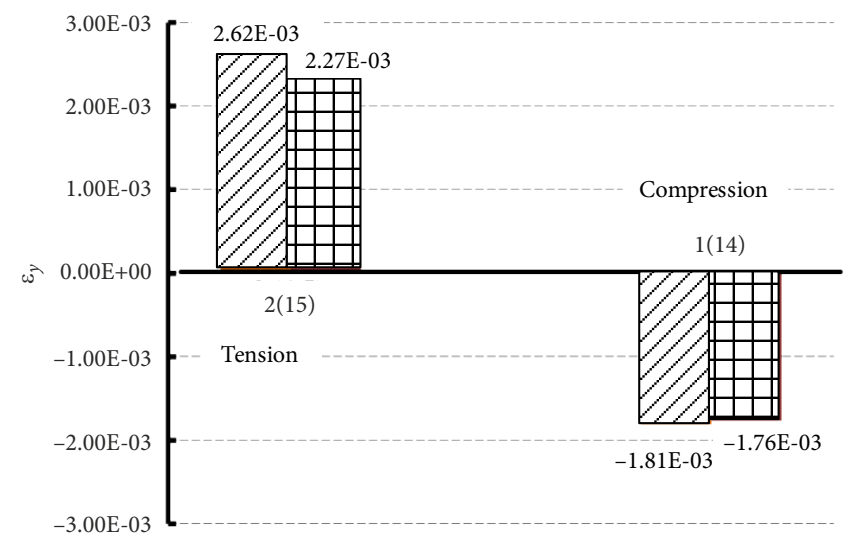

Experiment $\amalg$ Numerical cal.

Figure 9. Strains in experiment and numerical model: a) test scheme; b) diagrams of strains values

In Figure 8 cracks opened in sample and in numerical model are shown and force size at which crack has opened is indicated. It is seen in model of Figure 8 that the mode of crack opening is very similar. That is, the first crack in sample opened at force of $150 \mathrm{kN}$, and in numerical model - at force of $110 \mathrm{kN}$. The results show that numerical modeling strain mode is similar to that of experimental sample. The same situation is with crack which opened at added load. During test the sample collapsed ad force of $684 \mathrm{kN}$, and numerical model - at force of $545 \mathrm{kN}$. A $25.5 \%$ reserve is obtained.

The tensile and compressive strains of a fragment of compressed numerical masonry wall model in the edge sections of the sample are close to experimental values. That is, a small difference was found: in compressed area formed only $2.8 \%$, and in tensile area - up to $13.4 \%$. It shows that numerical modeling of compressed masonry behaviour gives sufficiently accurate and reliable results (see Figure 9).

\section{Conclusions}

The results of experimental research and numerical modeling have shown that in both cases defined distribution character of compressed masonry strains is uniform. Crack formation load estimated during experiments was equal to $684 \mathrm{kN}$, and the one estimated in numerical modeling - to $545 \mathrm{kN}$. Bearing capacity of sample estimated during experiment was up to $25.5 \%$ higher than that in numerical modeling.

Simplified micromodeling may be applied to investigate stress strain state of masonry structures. Estimated during simplified modeling state of compressed masonry stress and strain corresponds well enough to the results of experimental research. When making a numerical model of compressed masonry, it is expedient to describe mechanical properties of bed joint mortar using reduced properties determined by estimating impact of contact area.

The stress distribution angle was found to be close to $60^{\circ}$. It can be assumed that in the case of close contact of masonry units in unfilled head joints, horizontal stresses are transmitted by bed joints. 


\section{References}

Angelillo, M. (2014). Mechanics of masonry structures. In M. Angelillo, P. B. Lourenco, \& G. Milani (Eds.), CISM International Centre for Mechanical Sciences book series (CISM, vol. 551). Springer. https://doi.org/10.1007/978-3-7091-1774-3

Atkočiūnas, J., \& Nagevičius, J. (2004). Elastic theory basics. Technika (in Lithuanian).

Bigoni, D., \& Noselli, G. (2010a). Localized stress percolation through dry masonry walls. Part I - Experiments. European Journal of Mechanics - A/Solids, 29(3), 291-298. https://doi.org/10.1016/j.euromechsol.2009.10.009

Bigoni, D., \& Noselli, G. (2010b). Localized stress percolation through dry masonry walls. Part II - Modelling. European Journal of Mechanics - A/Solids, 29(3), 299-307. https://doi.org/10.1016/j.euromechsol.2009.10.013

Drobiec, Ł. (2017). FEM model of the masonry made of hollow calcium silicate units. Procedia Engineering, 193, 462-469. https://doi.org/10.1016/j.proeng.2017.06.238

Europen Commitee for Standartization. (2005). Eurocode 6: Design of masonry structures - Part 1-1: General rules for reinforced and unreinforced masonry structures (EN 1996-1-1:2005).

fib. CEB-FIP. (1998). CEB-FIP model code 1990. Switzerland.

Vermeltfoort, A. T. (2005). Brick-mortar interaction in masonry under compresion. Eindhoven University of Technology. Eindhoven University Press Facilities.

Jonaitis, B. (2005). Mokslo darbo mūro iš silikatiniu bloku „silka“ (arko $m$ ) mechaniniu savybiu tyrimas ataskaita. Lietuvos valstybinis mokslo ir studiju fondas. Vilniaus Gedimino technikos universitetas (in Lithuanian).

Lourenco, P. B., Rots, J. G., \& Blaauwendraad, J. (1995). Two approaches for the analyses of masonry structures: Micro and macro-modeling. HERON, 40(4), 313-340.

Lietuvos standartizacijos departamentas. (2004). Mūro skiedinio bandymo metodai. 11 dalis. Sukietejusio skiedinio stiprio lenkiant ir gniuždant nustatymas (LST EN 1015-11:2004) (in Lithuanian).

Mohammed, M. S. (2010). Finite element analysis of unreinforced masonry walls. Al-Rafidain Engineering Journal, 18(4), 55-68. https://doi.org/10.33899/rengj.2010.31528

Onischick, L. I. (1939). Masonry construction in industrial and civil buildings. Mascow State publishing house of building literature (in Russian).

Page, A. W., \& Hendry, A. W. (1988). Design rules for concentrated loads on masonry. The Structural Engineer, 66(17), 272-281.

Roca, P., Gonzalez, J. L., Onate, E., \& Lourenco, P. B. (1998). Experimental and numerical issues in the modelling of the mechanical behaviour of masonry. Structural analysis of historical constructions II. CIMNE, Barcelona.

Senthivel, R., \& Lourenco, P. B. (2009). Finite element modelling of deformation characteristics of historical stone masonry shear walls. Department of Civil Engineering, University of Minho, Guimarães, Portugal.

Symakezis, C. A., \& Asteris, P. G. (1999, June 6-9). Design recommendations for masonry walls under concentrated loads [Conference presentation]. 8th North American Masonry Conference, Austin, Texas.

Manie, J. (Ed.). (2011). DIANA finite element analysis. User's manual. Realease notes realeas 9.4.4. TNO DIANA BV. Netherlands.
Venckevičius, V. (2005). About the calculation of concrete elements subjected to local compression. Civil Engineering and Managment, 11(3), 243-248.

https://doi.org/10.1080/13923730.2005.9636355

Wijffels, T. J., \& Adan, O. C. G. (2004, July). Bond stenght in calcium silicate facing brick masonry. In $13^{\text {th }}$ International Brick and Block Masonry Conference (pp. 1-12). Amsterdam.

Zavalis, R., Jonaitis, B., \& Lourenco, B. P. (2018). Experimental investigation of the bed joint influence on mechanical properties of hollow calcium silicate block masonry. Materials and Structures, 51, 85. https://doi.org/10.1617/s11527-018-1215-y 